\title{
Role of indacaterol and the newer very long-acting $\beta 2$-agonists in patients with stable COPD: a review
}

This article was published in the following Dove Press journal:

International Journal of COPD

17 September 2013

Number of times this article has been viewed

\author{
Erminia Ridolo' \\ Marcello Montagni' \\ Elisa Olivieri' \\ Gian Galeazzo Riario- \\ Sforza ${ }^{2}$ \\ Cristoforo Incorvaia ${ }^{2}$ \\ 'Department of Clinical and \\ Experimental Medicine, University \\ of Parma, Parma, ${ }^{2}$ Pulmonary \\ Rehabilitation Unit, ICP Hospital, \\ Milan, Italy
}

Correspondence: Erminia Ridolo Department of Clinical and Experimental Medicine, University of Parma, Via Gramsci I6, 43I00 Parma, Italy Tel +39052I 702028

Fax +390521 703920

Email erminia.ridolo@unipr.it

\begin{abstract}
Bronchodilators are central drugs in the management of patients with chronic obstructive pulmonary disease (COPD). Indacaterol was the first agent of the novel family of very long-acting $\beta 2$-agonists to be used as an inhaled bronchodilator for COPD and provides 24-hour therapeutic action, thus allowing once-daily administration. Data from clinical trials show that indacaterol has a bronchodilator effect similar to that of the anticholinergic tiotropium bromide and slightly higher efficacy compared with the long-acting $\beta 2$-agonists, salmeterol and formoterol. Moreover, the safety profile is excellent and comparable with that of placebo. Concerning adherence with drug treatment and real-life management in respect to long-acting $\beta 2$-agonists, once-daily dosing makes indacaterol more convenient for COPD patients and is likely to enhance patient adherence. Other very long-acting $\beta 2$-agonists currently in development include vilanterol, olodaterol, and carmoterol, and these have shown good characteristics for clinical use in the studies reported thus far.
\end{abstract}

Keywords: chronic obstructive pulmonary disease, bronchodilators, very long-acting $\beta 2$-agonists

\section{Introduction}

Inhaled bronchodilators have a central role in the treatment of chronic obstructive pulmonary disease (COPD) because they reduce respiratory symptoms, increase exercise tolerance, reduce the frequency of exacerbations, and improve quality of life. Bronchodilators include anticholinergic agents and $\beta 2$-agonists, which are the currently recommended maintenance treatment for COPD. ${ }^{1}$ Short-acting bronchodilators (salbutamol, ipratropium bromide) are the most effective drugs for rapidly improving respiratory symptoms as needed, while long-acting $\beta 2$-agonists, such as salmeterol and formoterol, and the long-acting muscarinic antagonist, tiotropium bromide, are used in the treatment of stable disease. ${ }^{2,3}$ Aclidinium bromide and glycopyrronium bromide were recently introduced as new long-acting muscarinic antagonists. The ability of $\beta 2$-agonists to relax airway smooth muscle is due to their binding to the active site of $\beta 2$-adrenoceptors on such muscle, which induces a signaling cascade resulting in muscle relaxation. ${ }^{4}$ Based on the duration of this effect, long-acting $\beta 2$-agonists need twice-daily administration. Indacaterol was introduced in 2009 as the first once-daily, long-acting $\beta 2$-agonist approved in the European Union for maintenance bronchodilator treatment of airflow obstruction in adult patients with COPD, to be administered at doses of $150 \mu \mathrm{g}$ or $300 \mu \mathrm{g}$, and with the denomination of an ultra long-acting $\beta 2$-agonist. ${ }^{5}$ Drugs belonging to this new class may also be defined as very long-acting $\beta 2$-agonists (VLABAs), and include indacaterol and a 
number of agents currently under development that provide sustained bronchodilation comparable with that of longacting $\beta 2$-agonists, allowing once-daily administration for patients with COPD. ${ }^{6}$ Table 1 shows the main characteristics of the available bronchodilators. Adherence with long-acting $\beta 2$-agonists in COPD patients is low, being estimated at $54 \%$, so an effective once-daily $\beta 2$-agonist would be a significant improvement in terms of adherence with bronchodilator therapy, reducing the morbidity and health care costs of the disease related to nonadherence. ${ }^{7}$

Here we review the evidence from randomized trials concerning the efficacy and safety of indacaterol with respect to placebo, the long-acting $\beta 2$-agonists, and tiotropium, and summarize the characteristics of the VLABAs under current development.

\section{Indacaterol: efficacy data Placebo-controlled trials}

The efficacy of indacaterol was shown by several trials in terms of improvement in lung function as well as clinical outcomes and quality of life. Most of these trials included patients with moderate or severe COPD, defined as a postbronchodilator forced expiratory volume in one second $\left(\mathrm{FEV}_{1}\right)<80 \%$ and $\geq 30 \%$ of the predicted value and a post-bronchodilator $\mathrm{FEV}_{1}$ /forced vital capacity $<70 \%$. Spirometry-based end points included 24-hour post-dose $\mathrm{FEV}_{1}$ (measured 24 hours after the previous dose) and other time points post dose (from 5 minutes to 24 hours); an increase in $\mathrm{FEV}_{1}$ of $120 \mathrm{~mL}$ was considered to be the threshold for clinical relevance. Beyond lung function parameters, patient-orientated clinical end points were considered, ie, symptoms, dyspnea, exacerbation rates, use of rescue medication, days with no symptoms, and exercise tolerance. Evaluation of symptoms and health status was done using questionnaires like the St George's Respiratory Questionnaire (SGRQ), Transition Dyspnea Index (TDI), and the modified Medical Research Council scale. ${ }^{8}$ The main data from the trials on indacaterol are reported in Table 2.

The first study was conducted with a trial design comprising two phases. The INHANCE (INdacaterol to Help Achieve New COPD treatment Excellence) study included a dose-finding stage with dose selection after 2 weeks of treatment, and a second stage evaluating efficacy and safety during 26 weeks of treatment. ${ }^{9}$ In the dose-finding stage, patients were randomized into seven arms, ie, double-blind indacaterol $75,150,300$, or $600 \mu \mathrm{g}$ once daily, the longacting $\beta 2$-agonist formoterol $12 \mu \mathrm{g}$ twice daily or placebo, or tiotropium $18 \mu \mathrm{g}$ once daily. Selected doses of indacaterol (150 $\mu \mathrm{g}$ and $300 \mu \mathrm{g})$ were continued into the second stage for up to 26 weeks, while the other two indacaterol doses and formoterol were discontinued (see further on in this paper, in the discussion of indacaterol versus tiotropium).

As an extension to 6 months of the previous dosefinding INHANCE study, the INDORSE (INdacaterol DOse-finding extension on long teRm increaSe of $\mathrm{FEV}_{1}$ ) study assessed the long-term efficacy of indacaterol $150 \mu \mathrm{g}$ and $300 \mu \mathrm{g}$ once daily versus placebo. ${ }^{10}$ Concerning functional parameters, indacaterol increased the $\mathrm{FEV}_{1}$ compared with placebo throughout the study, reaching the clinical threshold (difference of $\geq 170 \mathrm{~mL}$ at week 52). Indacaterol achieved significant reductions in COPD exacerbations and as-needed albuterol use. An improvement in health status (by SGRQ scores) was highlighted with active treatment. ${ }^{10}$

In the INLIGHT (INdacaterol efficacy evaLuation using $150 \mu \mathrm{g}$ doses witH COPD paTients) study, Feldman et al evaluated the efficacy of indacaterol $150 \mu \mathrm{g}$ once daily versus placebo in a large population of patients for 12 weeks. ${ }^{11}$ Indacaterol significantly reduced the use of rescue medication and also the rate of days of poor control versus placebo. A significant difference in favor of indacaterol was found both at day 1 and after week 1 ; at week 12, the 24-hour postdose $\mathrm{FEV}_{1}$ was $130 \mathrm{~mL}$ higher than in the placebo group.

Table I Main characteristics of inhaled bronchodilators

\begin{tabular}{llll}
\hline Drug class & Onset of action & Duration of action & Administration \\
\hline Short-acting $\beta$ 2-agonists & Rapid & Up to 6 hours & As rescue medication \\
Long-acting $\beta$ 2-agonists & Formoterol: rapid & I2 hours & Maintenance treatment TD \\
& Salmeterol: slow & & \\
Very long-acting $\beta$ 2-agonists & Rapid & 24 hours & Maintenance treatment OD \\
Short-acting muscarinic antagonists & Rapid & Up to 6 hours & As rescue medication \\
Long-acting muscarinic antagonists & Slow for tiotropium bromide & Aclidinium bromide 12 hours & Maintenance treatment TD \\
& and aclidinium bromide & Tiotropium bromide 24 hours & Maintenance treatment OD \\
& Rapid for glycopyrronium bromide & Glycopyrronium bromide 24 hours & Maintenance treatment OD \\
\hline
\end{tabular}

Abbreviations: TD, twice daily; OD, once daily. 
Table 2 Details of trials on indacaterol

\begin{tabular}{|c|c|c|c|c|c|c|}
\hline Trial & $\begin{array}{l}\text { Patients, } \mathbf{n} \\
\text { (completed) }\end{array}$ & Duration & Design & Indacaterol & $\begin{array}{l}\text { Control } \\
\text { group }\end{array}$ & Outcomes \\
\hline INDORSE $^{10}$ & $414(336)$ & 52 weeks & $\begin{array}{l}\text { Core: randomized, double-blind } \\
\text { indacaterol or placebo, open-label } \\
\text { tiotropium ( } 26 \text { weeks) } \\
\text { Extension: subjects previously } \\
\text { randomized to indacaterol } \\
\text { or placebo continued double-blind } \\
\text { treatment ( } 26 \text { weeks) }\end{array}$ & $\begin{array}{l}150 \mu \mathrm{g} \text { OD } \\
300 \mu \mathrm{g} \text { OD }\end{array}$ & Placebo & $\begin{array}{l}\text { 24-hour FEV, at } 52 \text { weeks, } \\
\text { exacerbations, SGRQ }\end{array}$ \\
\hline INABLE $^{12}$ & $90(74)$ & 21 days & $\begin{array}{l}\text { Randomized, double-blind, } \\
\text { placebo-controlled, } \\
\text { two-period crossover }\end{array}$ & $300 \mu \mathrm{g} O D$ & Placebo & $\begin{array}{l}\text { Exercise endurance time at } \\
\text { week } 3, \text { IC, } 75 \text { minutes post dose } \\
\text { FEV, and FVC }\end{array}$ \\
\hline INLIGHT I"I & $416(364)$ & 12 weeks & Double-blind, parallel-group & $150 \mu \mathrm{g} O D$ & Placebo & $\begin{array}{l}24 \text {-hour } \mathrm{FEV} \text {, at week } 12 \text {, use } \\
\text { rescue medication, percentage } \\
\text { of days of poor control }\end{array}$ \\
\hline INSIST $^{14}$ & I,I $23(I, 034)$ & 12 weeks & Randomized, parallel-group & $150 \mu \mathrm{g} O D$ & $\begin{array}{l}\text { Salmeterol } \\
50 \mu \mathrm{g} \text { TD }\end{array}$ & $\begin{array}{l}\text { FEV, standardized area under } \\
\text { curve from } 5 \text { minutes to II hours } \\
\text { and } 45 \text { minutes and } 24 \text {-hour FEV, } \\
\text { at week I2, TDI, use of rescue } \\
\text { medication }\end{array}$ \\
\hline INLIGHT $2^{13}$ & $\mathrm{I}, 002(838)$ & 26 weeks & Randomized, double-blind & $150 \mu \mathrm{g} O D$ & $\begin{array}{l}\text { Salmeterol } \\
50 \mu \mathrm{g} \text { TD }\end{array}$ & $\begin{array}{l}\text { 24-hour FEV, at week 12, SGRQ, } \\
\text { dyspnea }\end{array}$ \\
\hline INTEGRAL ${ }^{15}$ & $68(6 I)$ & I4 days & $\begin{array}{l}\text { I4-day block crossover. } \\
\text { Randomized, double-blind } \\
\text { indacaterol or placebo, open-label } \\
\text { salmeterol }\end{array}$ & $300 \mu \mathrm{g}$ OD & $\begin{array}{l}\text { Placebo } \\
\text { Salmeterol } \\
5 \mu g \text { TD }\end{array}$ & 24-hour FEV , at day 14 \\
\hline INVOLVE $^{16}$ & $\mathrm{I}, 732(\mathrm{I}, 282)$ & 52 weeks & $\begin{array}{l}\text { Randomized, double-blind } \\
\text { double-dummy }\end{array}$ & $\begin{array}{l}300 \mu \mathrm{g} \text { OD } \\
600 \mu \mathrm{g} \text { OD }\end{array}$ & $\begin{array}{l}\text { Placebo } \\
\text { Formoterol } \\
12 \mu \mathrm{TD}\end{array}$ & $\begin{array}{l}\text { 24-hour FEV, at week I2, TDI, } \\
\text { use of rescue medication, SGRQ, } \\
\text { exacerbations, symptoms on diary } \\
\text { cards }\end{array}$ \\
\hline INTIME $^{17}$ & $169(153)$ & I4 days & $\begin{array}{l}\text { I4-days incomplete block } \\
\text { (three of the four treatments) } \\
\text { crossover }\end{array}$ & $\begin{array}{l}150 \mu \mathrm{g} \text { OD } \\
300 \mu \mathrm{g} \text { OD }\end{array}$ & $\begin{array}{l}\text { Placebo } \\
\text { Tiotropium } \\
18 \mu \mathrm{g} \text { OD }\end{array}$ & 24-hour FEV , at day 14 \\
\hline $\mathrm{INHANCE}^{18}$ & I,683 (I,29I) & 26 weeks & $\begin{array}{l}\text { Double-blind indacaterol } \\
\text { or placebo, open-label } \\
\text { tiotropium }\end{array}$ & $\begin{array}{l}150 \mu \mathrm{g} \text { OD } \\
300 \mu \mathrm{g} \text { OD }\end{array}$ & $\begin{array}{l}\text { Placebo } \\
\text { Tiotropium } \\
\text { I } 8 \mu \mathrm{g} \text { OD }\end{array}$ & $\begin{array}{l}\text { 24-hour FEV, at week I2, TDI, } \\
\text { SGRQ, exacerbations }\end{array}$ \\
\hline INTENSITY'19 & I,593 $(1,477)$ & 12 weeks & $\begin{array}{l}\text { Randomized, parallel-group, } \\
\text { blinded, double-dummy }\end{array}$ & $150 \mu \mathrm{g}$ OD & $\begin{array}{l}\text { Tiotropium } \\
18 \mu \mathrm{g} \text { OD }\end{array}$ & $\begin{array}{l}\text { 24-hour FEV, at week I2, TDI, } \\
\text { SGRQ, use of rescue medications, } \\
\text { days with no symptoms }\end{array}$ \\
\hline
\end{tabular}

Abbreviations: INDORSE, INdacaterol DOse-finding extension on long teRm increaSe of FEV, study; INABLE, INdacaterol: endurAnce, exercise-Based, and Lung Evaluation study; INLIGHT, INdacaterol efficacy evaLuation using $150 \mu \mathrm{g}$ doses witH COPD paTients studies; INTEGRAL, INdacaterol: Twenty four hours Efficacy duration using salmeterol study; INVOLVE, Indacaterol value in COPD longer term Validation of Efficacy and safety study; INTIME, INdacaterol and Tlotropium: Measuring Efficacy study; INHANCE, INdacaterol to Help Achieve New COPD treatment Excellence study; INTENSITY, INdacaterol Towards Establishment of cliNical SuperiorITY study; IC, inspiratory capacity; TD, twice daily; OD, once daily; SGRQ, Saint George Respiratory Questionnaire; TDI, Transition Dyspnea Index; FVC, forced vital capacity; FEV, forced expiratory volume in one second.

Inspiratory capacity, which is an index of end expiratory lung volume, was investigated during exercise and at rest in the INABLE (INdacaterol: endurAnce, exercise-Based, and Lung Evaluation) study. Inspiratory capacity is a valid indirect indicator of functional residual capacity and thus of the degree of lung hyperinflation. In patients treated with indacaterol $300 \mu \mathrm{g}$ once daily, inspiratory capacity was significantly improved versus placebo, with regard to both the resting value and the increased end-exercise value after 3 weeks, indicating a reduction in lung hyperinflation. ${ }^{12}$
Exercise endurance time was longer with indacaterol than with placebo after the first dose and after 3 weeks.

\section{Trials versus twice-daily, long-acting $\beta 2$-agonists}

Several studies have compared the efficacy and safety of indacaterol against the twice-daily, long-acting $\beta 2$-agonists, salmeterol and formoterol, in patients with moderate-tosevere COPD defined according to international COPD guidelines. The primary end point of these studies was 
24-hour post-dose $\mathrm{FEV}_{1}$; other patient-related outcomes considered were breathlessness, as-needed use of shortacting bronchodilators, exacerbations, and health status. The efficacy of once-daily indacaterol $150 \mu \mathrm{g}$ versus twicedaily salmeterol $50 \mu \mathrm{g}$ was investigated in the INLIGHT-2 (Indacaterol efficacy evaluation using $150 \mu \mathrm{g}$ doses with COPD patients), and INSIST (INdacaterol: investigating SuperiorIty versus SalmeTerol) studies. ${ }^{13,14}$ The 24-hour post-dose $\mathrm{FEV}_{1}$ after 12 weeks in the indacaterol group was $170 \mathrm{~mL}$ higher than in the placebo group and $60 \mathrm{~mL}$ higher than in the salmeterol group, and remained higher at week 26. Patients receiving indacaterol used less rescue medication and had a greater percentage of days with no rescue use. Active treatments (both indacaterol and salmeterol) improved the TDI and health status as assessed by SGRQ compared with placebo, with differences between the two active treatments favoring indacaterol.

In the INTEGRAL (INdacaterol: Twenty four hours Efficacy duration using salmeterol) study, patients were randomized to receive indacaterol $300 \mu \mathrm{g}$ once daily, salmeterol $50 \mu \mathrm{g}$ twice daily, or placebo daily. $\mathrm{FEV}_{1}$ on day 14 (the primary end point) was $200 \mathrm{~mL}$ higher than in the placebo group and $90 \mathrm{~mL}$ higher than in the salmeterol group. $\mathrm{FEV}_{1}$ was also assessed at different time points on days 1 and 14; indacaterol was significantly more effective than placebo at all time points, and showed a significantly higher $\mathrm{FEV}_{1}$ compared with salmeterol at many post-baseline time points, including 5 minutes post dose..$^{15}$

Comparison with formoterol also resulted in a favorable profile for functional and clinical end points. Dahl et al compared the efficacy and safety of indacaterol $300 \mu \mathrm{g}$ and $600 \mu \mathrm{g}$ with that of the twice-daily, long-acting $\beta 2$-agonist formoterol $12 \mu \mathrm{g}$ over one year in patients with moderate-tosevere COPD in the INVOLVE (Indacaterol value in COPD longer term Validation of Efficacy and safety) study. ${ }^{16}$ The primary efficacy variable was $\mathrm{FEV}_{1}$ measured 24 hours post dose after 12 weeks. The 24-hour post-dose $\mathrm{FEV}_{1}$ at week 12 significantly increased on indacaterol (both doses) versus both placebo and formoterol, maintaining a significant difference at the 52-week evaluation. All symptomatic outcomes improved with both active treatments compared with placebo. Both drugs significantly reduced the risk compared with placebo when the time to first COPD exacerbation was evaluated.

\section{Trials versus tiotropium}

The long-acting anticholinergic tiotropium bromide was also compared with indacaterol. The first controlled trial that compared the bronchodilation obtained with indacaterol and tiotropium was INTIME (INdacaterol and TIotropium: Measuring Efficacy). Patients received indacaterol $150 \mu \mathrm{g}$ or $300 \mu \mathrm{g}$, tiotropium $18 \mu \mathrm{g}$, and placebo each for 14 days, separated by a 14-day washout between each treatment period. Both treatments were significantly more effective than placebo. Once-daily indacaterol at doses of $150 \mu \mathrm{g}$ and $300 \mu \mathrm{g}$ was at least as effective as tiotropium, but had a faster onset of action (within 5 minutes) on the first day of dosing. ${ }^{17}$ Two other trials including larger populations of patients were conducted, ie, the INHANCE study that, in the second stage, compared the efficacy of indacaterol (150 $\mu \mathrm{g}$ and $300 \mu \mathrm{g}$ ) with placebo and tiotropium over 12 weeks of treatment, and the INTENSITY (INdacaterol Towards Establishment of cliNical SuperiorITY) study, which demonstrated the noninferiority of indacaterol $150 \mu \mathrm{g}$ once daily versus tiotropium using $\mathrm{FEV}_{1}$ values, but also symptom assessment by the TDI and SGRQ, and use of rescue medication. ${ }^{18,19}$ Regarding functional end points, both treatments were effective against placebo; in the INHANCE trial, after week 12 in patients receiving indacaterol, the 24-hour post-dose $\mathrm{FEV}_{1}$ increased versus placebo by $180 \mathrm{~mL}$ (with indacaterol doses of $150 \mu \mathrm{g}$ and $300 \mu \mathrm{g}$ ) and in patients receiving tiotropium by $140 \mathrm{~mL}$ versus placebo, thereby achieving the threshold for clinical relevance in both treatment groups. In the second trial, absolute $\mathrm{FEV}_{1}$ values were $1.44 \mathrm{~L}$ with indacaterol and $1.43 \mathrm{~L}$ with tiotropium at week 12 , such a difference being comparable. The mean TDI score significantly increased compared with placebo at all time points with both active treatments, and there was also a significant difference between indacaterol $300 \mu \mathrm{g}$ and tiotropium at weeks 4,8 , and 12. Indacaterol-treated patients used less rescue albuterol than tiotropium-treated patients and had a higher proportion of days without any rescue use and of nights without awakenings. In both trials, the incidence of adverse events was similar across treatments.

\section{Indacaterol: safety and tolerability data}

Inhaled $\beta 2$-agonists can have systemic effects due to their bioavailability; such effects, mediated by stimulation of $\beta 2$-adrenergic receptors, are particularly important in the cardiovascular system and include tachycardia, increased blood pressure, a prolonged QT interval, hyperglycemia, hypokalemia, and muscle tremors. It must be considered that many patients with COPD are elderly and often have several comorbidities, so it is particularly important to evaluate the safety of maintenance bronchodilator treatment. 
The safety and tolerability of indacaterol was evaluated in all the relevant clinical trials, so could be assessed in a large population of patients with COPD at the approved doses of $150 \mu \mathrm{g}$ and $300 \mu \mathrm{g}$ (in the US, only the $75 \mathrm{mg}$ dose is approved by the US Food and Drug Administration) and also at the higher dose (not approved for clinical use) of $600 \mu \mathrm{g}$ daily for up to one year without observation of significant issues.

Data from clinical studies of 12-52 weeks' duration in patients with moderate-to-severe COPD receiving double-blind indacaterol at doses of $75 \mu \mathrm{g}$ (449 patients), $150 \mu \mathrm{g}(2,611$ patients), $300 \mu \mathrm{g}$ (1,157 patients), and $600 \mu \mathrm{g}$ (547 patients) once daily compared with formoterol $12 \mu \mathrm{g}$ twice daily (556 patients), salmeterol $50 \mu \mathrm{g}$ twice daily (895 patients), tiotropium $18 \mu \mathrm{g}$ once daily (1,214 patients), or placebo (2,012 patients) were screened. ${ }^{20}$ The incidence of adverse events was similar in the indacaterol and placebo groups and, in most cases, reflected the typical signs and symptoms of COPD itself. Also, the risk of a "serious adverse event" (fatal or life-threatening, resulting in persistent or significant disability/incapacity, constituting a congenital anomaly/birth defect, requiring inpatient hospitalization or prolongation of existing hospitalization, or medically significant), including acute respiratory events, was similar in all indacaterol groups compared with placebo. Systemic $\beta 2$-adrenoceptor-mediated effects (on QTc interval, plasma potassium, and blood glucose) were rare and showed no clinically significant changes with indacaterol treatment.

Cough, usually mild and transient, was frequently reported in the trials, a few minutes after inhalation, by up to $20 \%$ of patients. ${ }^{11,14,15,18}$ In the study by Feldman et al, worsening of COPD and cough were the most frequent adverse effects; the onset of cough following inhalation was predominantly within 15 seconds of inhalation and was not associated with bronchospasm or any increase in study discontinuation rates. ${ }^{11}$ Cough occurred at a higher frequency in the indacaterol groups compared with placebo $(2.9 \%-12.4 \%$ versus $0.9 \%$ ) in a dose-ranging trial; however, the incidence decreased over the course of the study, and the incidence on indacaterol was similar to that on placebo after 7 days. ${ }^{21}$

Indacaterol has a good cardiovascular safety profile in patients with COPD. $\beta 2$-agonists, like other adrenergic compounds, can prolong the QT interval. In one randomized, double-blind, parallel-group, placebo-controlled, and positive-controlled study in healthy subjects, 404 individuals were randomized to receive indacaterol (at doses of 150, 300 or $600 \mu \mathrm{g}$ ), placebo, or placebo/moxifloxacin. ${ }^{22}$ The primary endpoint was the change in QTcF (QT interval corrected for heart rate using Fridericia's formula) from baseline on day 14 . In this study, indacaterol did not show any clinically relevant effect on the QT interval, with maximal time-matched mean treatment differences from placebo in QTcF change from baseline on day 14 of $2.66,2.98$, and $3.34 \mathrm{msec}$ for indacaterol $150 \mu \mathrm{g}, 300 \mu \mathrm{g}$, and $600 \mu \mathrm{g}$, respectively.

Analysis of clinical trials including 4,635 patients with moderate-to-severe COPD who were enrolled into studies of at least 6 months' duration and treated with indacaterol, placebo, or other bronchodilators (formoterol, salmeterol, tiotropium) showed that the cardiovascular and cerebrovascular safety profiles were similar to those for placebo and comparable with those for other long-acting $\beta 2$-agonists. ${ }^{23}$ Moreover, the safety of a single supratherapeutic dose of indacaterol was also investigated. ${ }^{24}$ Single doses of indacaterol $400,1,000,2,000$, and 3,000 $\mu \mathrm{g}$ were given to patients with moderate or severe COPD, with minimal systemic effects and no clinically significant electrocardiographic changes.

\section{Issue of adherence}

Adherence with treatment is certainly a major problem in patients with chronic disease, and less than $50 \%$ of patients receiving drug therapy follow it according to the physician's directions. ${ }^{25}$ In the treatment of COPD, once-daily administration is particularly attractive for patient drug compliance. ${ }^{26}$ In COPD, as for other chronic diseases, poor compliance is common and associated with increased rates of morbidity, health care expenditure, diminished quality of life, hospitalizations, and mortality. ${ }^{27}$

Incorvaia et al evaluated changes in adherence with drug treatment in patients with COPD receiving a structured educational program. ${ }^{28}$ The study included 100 patients who were prescribed drug treatment by their primary care physician according to the updated version of the guidelines on COPD. ${ }^{1}$ At the first visit, 34\% of patients had stopped one or more of the prescribed drugs without their physician's authorization, and $53 \%$ did not use the correct dosage, giving an adherence rate of $47 \%$. After the educational program, when patients attended the maintenance rehabilitation course 6 months later, the adherence rate had increased to $87.4 \%$. This shows that patient education can greatly improve adherence with prescribed drugs in patients with COPD. When the study was performed, indacaterol was not commercially available, so the adherence evaluation concerned longacting $\beta 2$-agonists, inhaled corticosteroids, given singly or in combination, and tiotropium. Once-daily dosing of indacaterol is more convenient for patients and is likely to represent a compliance-enhancing advantage. Randomized 
studies of the effects of patient education on adherence are warranted to improve further the role of indacaterol in COPD treatment. $^{29}$

\section{VLABAs in development Vilanterol}

Vilanterol trifenatate has shown high potency, selectivity, rapid onset, a long duration of action in vitro, and low oral bioavailability. Higher selectivity for the $\beta 2$-adrenoreceptor than salbutamol, formoterol, and indacaterol was detected. ${ }^{30}$ Table 3 reports the main data from the trials available on vilanterol thus far. A placebo-controlled trial in patients randomized to receive five doses of vilanterol $(3,6.25,12.5,25$, or $50 \mu \mathrm{g}$ ) or placebo once daily for 28 days found that the once-daily doses of $25 \mu \mathrm{g}$ and $50 \mu \mathrm{g}$ provided both statistically and clinically relevant 24-hour improvements in lung function compared with placebo. All doses of vilanterol had a safety and tolerability profile similar to that of placebo. ${ }^{31}$ The safety of vilanterol was confirmed in a trial evaluating the drug alone (at the dose of $50 \mu \mathrm{g}$ ) or in combination with umeclidinium, a long-acting muscarinic antagonist, at a dose of $500 \mu \mathrm{g}$.
Coadministration of single inhaled doses of umeclidinium and vilanterol to healthy subjects was well tolerated and not associated with meaningful changes in systemic exposure or pharmacodynamic effects compared with administration of either compound individually. ${ }^{32}$ Further, studies were performed on the association of vilanterol with an inhaled corticosteroid. In one trial in patients with moderate-to-severe COPD, fluticasone furoate/vilanterol 100/25 $\mu \mathrm{g}$ provided rapid and significant sustained bronchodilation at 24 weeks; improvement in lung function to a similar extent was found with fluticasone furoate/vilanterol $50 / 25 \mu \mathrm{g}$ and to a somewhat lesser extent with vilanterol $25 \mu \mathrm{g}$ alone. ${ }^{33}$ In another trial, fluticasone furoate/vilanterol provided rapid and significant sustained improvement in $\mathrm{FEV}_{1}$ in patients with moderateto-severe COPD, which was not influenced by the dose of fluticasone furoate. ${ }^{34}$

\section{Olodaterol}

Olodaterol was pharmacologically characterized in preclinical models in $2010 .{ }^{35}$ To evaluate the mechanisms behind its long duration of action, different aspects of olodaterol

Table 3 Details of trials on vilanterol

\begin{tabular}{|c|c|c|c|c|c|c|}
\hline Study & Patients (n) & Duration & Design & Interventions & Outcomes & Results \\
\hline $\begin{array}{l}\text { Hanania } \\
\text { et } \mathrm{al}^{31}\end{array}$ & 605 & 28 days & $\begin{array}{l}\text { Randomized, } \\
\text { double-blind study }\end{array}$ & $\begin{array}{l}\text { Vilanterol } \\
3 \mu \mathrm{g} \\
6.25 \mu \mathrm{g} \\
12.5 \mu \mathrm{g} \\
25 \mu \mathrm{g} \\
50 \mu \mathrm{g} \\
\text { Placebo }\end{array}$ & $\begin{array}{l}\text { 24-hour FEV, at } \\
\text { day } 28 \text {, use of rescue } \\
\text { medications }\end{array}$ & $\begin{array}{l}\text { Vilanterol showed a significant, } \\
\text { dose-dependent, improvement } \\
\text { in trough FEV, compared with } \\
\text { placebo }\end{array}$ \\
\hline $\begin{array}{l}\text { Kelleher } \\
\text { et } \mathrm{al}^{32}\end{array}$ & 16 & $\begin{array}{l}\text { Single } \\
\text { inhaled } \\
\text { dose }\end{array}$ & $\begin{array}{l}\text { Single-center, double- } \\
\text { blind, placebo-controlled, } \\
\text { four-way, randomized, } \\
\text { crossover trial }\end{array}$ & $\begin{array}{l}\text { Vilanterol } 50 \mu \mathrm{g} \\
\text { Umeclidinium } 500 \mu \mathrm{g} \\
\text { Placebo }\end{array}$ & $\begin{array}{l}\text { Safety } \\
\text { Pharmacodynamic } \\
\text { and pharmacokinetic } \\
\text { analysis }\end{array}$ & $\begin{array}{l}\text { Study treatments were safe and } \\
\text { well tolerated and no serious } \\
\text { adverse events or deaths were } \\
\text { reported }\end{array}$ \\
\hline $\begin{array}{l}\text { Kerwin } \\
\text { et } \mathrm{al}^{33}\end{array}$ & 1,030 & 24 weeks & $\begin{array}{l}\text { Multicenter, randomized, } \\
\text { placebo-controlled, } \\
\text { double-blind, } \\
\text { parallel-group study }\end{array}$ & $\begin{array}{l}\text { FF/vilanterol } \\
\qquad 100 / 25 \mu \mathrm{g} \\
50 / 25 \mu \mathrm{g} \\
\text { Vilanterol } 25 \mu \mathrm{g} \\
\text { FF } 100 \mu \mathrm{g} \\
\text { Placebo }\end{array}$ & 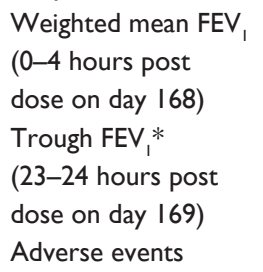 & $\begin{array}{l}\text { The combination FF/vilanterol } \\
\text { significantly improved FEV, } \\
\text { versus placebo } \\
\text { No significant difference was } \\
\text { seen between FF/VI 100/25 } \mu g \\
\text { and VI } 25 \mu \mathrm{g} \text { for trough FEV, }\end{array}$ \\
\hline $\begin{array}{l}\text { Martinez } \\
\text { et } \mathrm{al}^{34}\end{array}$ & I,224 & 24 weeks & $\begin{array}{l}\text { Multicenter, randomized, } \\
\text { double-blind, } \\
\text { placebo-controlled, } \\
\text { parallel-group study }\end{array}$ & $\begin{array}{l}\text { FF/vilanterol } \\
200 / 25 \mu \mathrm{g} \\
100 / 25 \mu \mathrm{g} \\
\text { Vilanterol } 25 \mu \mathrm{g} \\
\text { FF } 200 \mu \mathrm{g} \\
\text { FF I } 10 \mu \mathrm{g} \\
\text { Placebo }\end{array}$ & $\begin{array}{l}\text { Weighted mean FEV, } \\
(0-4 \text { hours post } \\
\text { dose on day I68) } \\
\text { trough FEV } * \\
(23-24 \text { hours post } \\
\text { dose on day } 169) \\
\text { Adverse events }\end{array}$ & $\begin{array}{l}\text { Significant increase in weighted } \\
\text { mean } \mathrm{FEV} \text {, and trough } \mathrm{FEV} \text {, } \\
\text { for FF/vilanterol } 200 / 25 \mu \mathrm{g} \text { and } \\
100 / 25 \mu \mathrm{g} \text { versus placebo. The } \\
\text { difference between FF/vilanterol } \\
200 / 25 \mu \mathrm{g} \text { and vilanterol } 25 \mu \mathrm{g} \\
\text { in change from baseline trough } \\
\text { FEV, was not statistically } \\
\text { significant }\end{array}$ \\
\hline
\end{tabular}

Note: *Trough FEV : mean volume of air that can be forced out in one second after taking a deep breath approximately 24 hours after the last administration of study drug. Abbreviations: FF, fluticasone furoate; $\mathrm{FEV}_{\text {, }}$, forced expiratory volume in one second; VI, vilanterol. 
were analyzed, including its lipophilicity and propensity to accumulate in the lipid bilayer, as well as its tight binding to the $\beta 2$-receptor. According to its physicochemical properties, olodaterol showed a moderate association with lipid bilayers, while kinetic as well as equilibrium binding studies indicated the presence of a stable $[(3) \mathrm{H}]$ olodaterol $/ \beta(2)-\mathrm{AR}$ complex with a dissociation half-life of 17.8 hours due to ternary complex formation. ${ }^{36}$

A double-blind, placebo-controlled, crossover study in 36 COPD patients including 24-hour spirometry, safety, tolerability, and pharmacokinetics (in a subset of patients) evaluated the effect of five doses of olodaterol $(2,5,10$, and $20 \mu \mathrm{g} ; 40 \mu \mathrm{g}$ in an open label extension phase). The mean baseline prebronchodilator $\mathrm{FEV}_{1}$ was $1.01 \mathrm{~L}$ (37\% of predicted). All doses of olodaterol gave significantly greater bronchodilation compared with placebo in 24 -hour $\mathrm{FEV}_{1}$ post dose $(P<0.001)$; a clear dose-response relationship was observed, with values ranging from $0.070 \mathrm{~L}$ for olodaterol $2 \mu \mathrm{g}$ to $0.119 \mathrm{~L}$ for olodaterol $20 \mu \mathrm{g}$. Pharmacokinetic evaluation of peak plasma concentrations and renal excretion suggested no obvious deviation from dose proportionality over the dose range investigated. All treatments were well tolerated. ${ }^{37}$

\section{Carmoterol}

Carmoterol is a non-catechol $\beta 2$-adrenoceptor agonist with structural elements from formoterol and procaterol. Carmoterol has a 53 times higher affinity for $\beta 2$-adrenoceptors than for $\beta 1$-adrenoceptors, mainly because of the methoxyphenyl group in the seventh transmembrane region. ${ }^{38}$ Its onset of action is rapid and prolonged, as showed by in vitro and in vivo studies. In particular, carmoterol demonstrated rapid activity in vitro comparable with that of formoterol and a longer duration of muscle relaxation than formoterol and salmeterol. ${ }^{39,40}$ Phase II studies investigated the safety and tolerability of carmoterol administered in multiple escalating doses to patients with COPD, with no significant dose-effect response concerning blood parameters or cardiovascular events. ${ }^{41}$ Controlled studies of its clinical efficacy are not yet available.

\section{Conclusion}

Bronchodilators are of central importance in the symptomatic management of COPD. Indacaterol was the first VLABA to be introduced, the 24-hour activity of which allows once-daily administration. This agent is now approved by the European Medicine Agency for the treatment of COPD. The available evidence shows that indacaterol provides efficacy comparable with, if not superior to, the other current bronchodilators used as maintenance treatment in terms of improving lung function and quality of life. Importantly, indacaterol is as rapidly effective as short-acting $\beta 2$-agonists on the first day of use, ${ }^{42}$ and this favors patient recognition of efficacy. Moreover, data from clinical trials indicate an excellent safety and tolerability profile, with a rate of adverse effects comparable with that of placebo; this includes cardiovascular effects, which are particularly important for $\beta 2$-agonists. Available data indicate similar efficacy and safety for other VLABAs, such as vilanterol (including in fixed combination with the inhaled corticosteroid fluticasone furoate and the long-acting muscarinic antagonist umeclidinium) and olodaterol. Compared with twice-daily, long-acting $\beta 2$-agonists, once-daily dosing of a VLABA appears to be more convenient for COPD patients and is likely to enhance their long-term adherence with treatment, which is a critical issue in the management of chronic diseases like COPD. On the other hand, the potential risks inherent with long-acting $\beta 2$-agonists, especially when patients with COPD plus asthma (who need a treatment based on inhaled corticosteroids) are treated only by VLABAs must not be overlooked.

\section{Disclosure}

The authors report no conflicts of interest in this work.

\section{References}

1. Vestbo J, Hurd SS, Agustí AG, et al. Global strategy for the diagnosis, management, and prevention of chronic obstructive pulmonary disease: GOLD executive summary. Am J Respir Crit Care Med. 2013;187: 347-365.

2. Tashkin DP, Fabbri LM. Long-acting beta-agonists in the management of chronic obstructive pulmonary disease: current and future agents Respir Res. 2010;11:149-163.

3. Keating GM. Tiotropium bromide inhalation power: a review of its use in the management of chronic obstructive pulmonary disease. Drugs. 2012;72:273-300.

4. Cazzola M, Page CP, Rogliani P, Matera MG. $\beta 2$-agonists therapy in lung disease. Am J Respir Crit Care Med. 2013;187:690-696.

5. Beeh KM, Beier J. The short, the long, and the "ultra-long": why duration of bronchodilator action matters in chronic obstructive pulmonary disease. Adv Ther. 2010;27:150-159.

6. Malerba M, Radaeli A, Morjaria JB. Therapeutic potential for novel ultra long acting beta2-agonists in the management of COPD: biological and pharmacological aspects. Drug Discov Today. 2012;17:496-504.

7. Cecere LM, Slatore CG, Uman JE, et al. Adherence to long-acting inhaled therapies among patients with chronic obstructive pulmonary disease (COPD). COPD. 2012;9:251-258.

8. Glaab T, Vogelmeier C, Buhl R. Outcome measures in chronic obstructive pulmonary disease (COPD): strengths and limitations. Respir Res. 2010;11:79-85.

9. Barnes P, Pocock SJ, Magnussen $\mathrm{H}$, et al. Integrating indacaterol dose selection in a clinical study in COPD using an adaptive and seamless design. Pulm Pharmacol. 2010;23:165-171.

10. Chapman KR. Rennard SI, Dogra A, Owen R, Lassen C, Kramer B; INDORSE Study Investigators. Long-term safety and efficacy of indacaterol, a long-acting beta2-agonist, in subjects with COPD: a randomized, placebo-controlled study. Chest. 2011;140:68-75. 
11. Feldman G, Siler T, Prasad N, et al; INLIGHT Study Group. Efficacy and safety of indacaterol $150 \mu \mathrm{g}$ once-daily in COPD: a double-blind, randomised, 12-week study. BMC Pulm Med. 2010;10: 11-20.

12. O’Donnell DE, Casaburi R, Vincken W, Puente-Maestu L, Swales J, Lawrence D; the INABLE Study Group. Effect of indacaterol on exercise endurance and lung hyperinflation in COPD. Respir Med. 2011;105:1030-1036.

13. Kornmann O, Dahl R, Centanni S, et al; the INLIGHT-2 Study Investigators. Once-daily indacaterol versus twice-daily salmeterol for COPD: a placebo-controlled comparison. Eur Respir J. 2011;37: 273-279.

14. Korn S, Kerwin E, Atis S, Amos C, Owen R, Lassen C; INSIST Study Group. Indacaterol once-daily provides superior efficacy to salmeterol twice-daily in COPD: a 12-week study. Respir Med. 2011;105: 719-726.

15. Laforce C, Aumann J, Parreno LD, Iqbal A, Young D, Owen R; INTEGRAL Study Investigators. Sustained 24-hour efficacy of oncedaily indacaterol $(300 \mu \mathrm{g})$ in patients with chronic obstructive pulmonary disease: a randomized, cross-over study. Pulm Pharmacol Ther. 2011;24:162-168.

16. Dahl R, Chung KF, Buhl R, et al; INVOLVE Study Investigators. Efficacy of a new once-daily inhaled beta2-agonist indacaterol versus twice-daily formoterol in COPD. Thorax. 2010;65:473-479.

17. Vogelmeier C, Ramos-Barbon D, Jack D, Piggott S, Owen R, Higgins M; INTIME Study Investigators. Indacaterol provides 24 -hour bronchodilation in COPD: a placebo-controlled blinded comparison with tiotropium. Respir Res. 2010;11:135-139.

18. Donohue JF, Fogarty C, Lotvall J, et al; INHANCE study investigators. Once-daily bronchodilators for chronic obstructive pulmonary disease: indacaterol versus tiotropium. Am J Respir Crit Care Med. 2010;182: $155-162$.

19. Buhl R, Dunn LJ, Disdier C, et al; INTENSITY Study Group. Blinded 12-week comparison of once-daily indacaterol and tiotropium in COPD. Eur Respir J. 2011;38:797-803.

20. Donohue JF, Singh D, Kornmann O, Lawrence D, Lassen C, Kramer B. Safety of indacaterol in the treatment of patients with COPD. Int J Chron Obstruct Pulmon Dis. 2011;6:477-492.

21. Rennard S, Bantje T, Centanni S, et al. A dose-ranging study of indacaterol in obstructive airways disease, with a tiotropium comparison. Respir Med. 2008;102:1033-1044.

22. Khindri S, Sabo R, Harris S, Woessner R, Jennings S, Drollmann AF. Cardiac safety of indacaterol in healthy subjects: a randomized, multidose, placebo- and positive-controlled, parallel-group thorough QT study. BMC Pulm Med. 2011;11:31.

23. Worth H, Chung KF, Felser JM, Hu H, Rueegg P. Cardio- and cerebrovascular safety of indacaterol versus formoterol, salmeterol, tiotropium and placebo in COPD. Respir Med. 2011;105:571-579.

24. Pascoe S, Reynolds C, Pleskow W, et al. Safety, tolerability and pharmacokinetics of single escalating doses of indacaterol, a oncedaily beta2-agonist bronchodilator, in subjects with COPD. Int J Clin Pharmacol Ther. 2011;49:153-161.

25. Cutler DM, Everett W. Thinking outside the pillbox - medication adherence as a priority for health care reform. N Engl J Med. 2010;362: $1553-1555$.
26. Jones PW, Barnes N, Vogelmeier C, Lawrence D, Kramer B. Efficacy of indacaterol in the treatment of patients with COPD. Prim Care Respir J. 2011;20:380-388.

27. Bourbeau J, Bartlett SJ. Patient adherence in COPD. Thorax. 2008;63: 831-838.

28. Incorvaia C, Riario-Sforza GG. Effect of patient education on adherence to drug treatment for chronic obstructive pulmonary disease. Ann Thorac Med. 2011;6:242-243.

29. Ribeiro M, Chapman KR. Comparative efficacy of indacaterol in chronic obstructive pulmonary disease. Int J Chron Obstruct Pulmon Dis. 2012;7:145-152.

30. Procopiou PA, Barrett VJ, Bevan NJ, et al. Synthesis and structureactivity relationships of long-acting beta2 adrenergic receptor agonists incorporating metabolic inactivation: an antedrug approach. $J$ Med Chem. 2010;53:4522-4530.

31. Hanania NA, Feldman G, Zachgo W, et al. The efficacy and safety of the novel long-acting $\beta 2$ agonist vilanterol in patients with COPD: a randomized placebo-controlled trial. Chest. 2012;142:119-127.

32. Kelleher DL, Mehta RS, Jean-Francois BM, et al. Safety, tolerability, pharmacodynamics and pharmacokinetics of umeclidinium and vilanterol alone and in combination: a randomized crossover trial. PloS One. 2012;7:e50716.

33. Kerwin EM, Scott-Wilson C, Sanford L, et al. A randomised trial of fluticasone furoate/vilanterol $(50 / 25 \mu \mathrm{g} ; 100 / 25 \mu \mathrm{g})$ on lung function in COPD. Respir Med. 2013;107:560-569.

34. Martinez FJ, Boscia J, Feldman G, et al. Fluticasone furoate/vilanterol $(100 / 25 ; 200 / 25 \mu \mathrm{g})$ improves lung function in COPD: a randomised trial. Respir Med. 2013;107:550-559.

35. Bouyssou T, Casarosa P, Naline E, et al. Pharmacological characterization of olodaterol, a novel inhaled beta2-adrenoceptor agonist exerting a 24-hour-long duration of action in preclinical models. $J$ Pharmacol Exp Ther. 2010;334:53-62.

36. Casarosa P, Kolak I, Kiechle T, et al. Functional and biochemical rationales for the 24-hour-long duration of action of olodaterol. J Pharmacol Exp Ther. 2011;337:600-609.

37. van Noord JA, Smeets JJ, Drenth BM, et al. 24-hour bronchodilation following a single dose of the novel 2-agonist olodaterol in COPD. Pulm Pharmacol Ther. 2011;24:666-672.

38. Kikkawa H, Isogaya M, Nagao T, Kurose $H$. The role of the seventh transmembrane region in high affinity binding of a beta 2 -selective agonist TA-2005. Mol Pharmacol. 1998;53:128-134.

39. Rosethorne EM, Turner RJ, Fairhurst RA, Charlton SJ. Efficacy is a contributing factor to the clinical onset of bronchodilation of inhaled beta(2)-adrenoceptor agonists. Naunyn Schmiedebergs Arch Pharmacol. 2010;382:255-263.

40. Voss HP, Shukrula S, Wu TS, Donnel D, Bast A. A functional beta-2 adrenoceptor-mediated chronotropic response in isolated guinea pig heart tissue: selectivity of the potent beta- 2 adrenoceptor agonist TA 2005. J Pharmacol Exp Ther. 1994;271:386-389.

41. Bateman ED. Carmoterol - safety and tolerability of a long-acting $\beta 2$ agonist in patients with COPD. Proc Am Thorac Soc. 2008;5:A653.

42. Vogelmeier C, Magnussen H, LaForce C, Owen R, Kramer B. Profiling the bronchodilator effects of the novel ultra-long-acting $\beta 2$-agonist indacaterol against established treatments in chronic obstructive pulmonary disease. Ther Adv Respir Dis. 2011;5:345-357.
International Journal of COPD

\section{Publish your work in this journal}

The International Journal of COPD is an international, peer-reviewed journal of therapeutics and pharmacology focusing on concise rapid reporting of clinical studies and reviews in COPD. Special focus is given to the pathophysiological processes underlying the disease, intervention programs, patient focused education, and self management protocols.
Dovepress

This journal is indexed on PubMed Central, MedLine and CAS. The manuscript management system is completely online and includes a very quick and fair peer-review system, which is all easy to use. Visit http://www.dovepress.com/testimonials.php to read real quotes from published authors. 